\begin{tabular}{|l|l|l|l|}
\hline Received 29/09/2019 & E & Published 25/10/2019 \\
\hline
\end{tabular}

\title{
Knowledge Management Implementation in Muhammadiyah Elementary School
}

\author{
${ }^{1}$ Hafidh Nur Fauzi, ${ }^{2}$ Umam Mufti \\ E-mail: hafidhnurfauzi90@gmail.com ${ }^{1}$, umammufti130@gmail.com ${ }^{1}$
}

${ }^{1,2}$ Universitas Ahmad Dahlan, Yogyakarta, Indonesia

ABSTRACT

Knowledge Management is a systematic step in managing intellectual assets/knowledge and various information from individuals and organizations to be able to compete in order to add value and innovation. On the other hand, knowledge is one of the agency's assets and can be a separate competitive advantage if it can be managed properly. Current problems are technological developments and increased competition between educational institutions. If an educational institution does not

Keywords Implementation; Knowledge Management; Muhammadiyah Elementary School have good knowledge management, of course, it will be left behind. Good management is needed and applied optimally. In Muhammadiyah Elementary School of Banguntapan, there are two management implementation aspects, namely identification of knowledge and identification of structures. Tacit and explicit factors as patterns of knowledge management development also require attention. If all of these factors are properly considered and applied, it will create a favorite school that has good knowledge management.

\section{INTRODUCTION}

Superior and quality human resources are important factors for service and non-service companies . With the current conditions of competition, people are aware that knowledge is an important factor in creating superiority over financial assets/money. Therefore, various fields of activity in Indonesia are currently required to carry out knowledge management in order to survive. In addition to managing skills that are in accordance with the competencies and needs of the organization, knowledge management is also needed as an effort to increase the competitiveness of business organizations or public organizations (Nuryana, 2017). Knowledge must be managed so that it can be planned and implemented. The process of organizational interaction with various elements requires a long time and process so that knowledge can help an education institution to win the competition (Mavodza \& Ngulube, 2012).

Management is a field of science that influences many aspects of human life. Management provides direction to recognize one's own abilities, strengths, and weaknesses. Management provides a more effective and efficient way of carrying out work so as to obtain the desired goals (Manuj \& Mentzer, 2008). To win business competition, a better organization/company is needed. Efforts to increase the quality of companies/organizations involve the concept of knowledge management including Human 
Resource Management (HRM) and Information Technology (IT). The development of information technology does have an important role in the concept of knowledge management. Almost all activities of human life are characterized by the mastery of information technology, so knowledge management cannot be separated from information technology management. To achieve these objectives, it is necessary to have superior human resources. Superior human resources are those who have knowledge, ideas, expertise, self-management, cooperation, and experience, and these are important assets for the company. The seven elements are capital that will not run out or just disappear. This is different from the financial element that will run out if it is not managed properly. Everyone must be able to develop a willingness to learn, ask questions, try, come up with ideas, and foster self-confidence (Salame \& Nazir, 2019).

Muhammadiyah Elementary School of Banguntapan, located on Jalan Wonosari KM. 3, Ketandan, Banguntapan, Bantul is trying to apply the knowledge management concept. This 68 -year-old school continues to try to become an outstanding school. This school has won various achievements in the fields of academics, sports, and arts. Theoretically, this school does not recognize the term knowledge management. Teachers in this school are more familiar with the term 'knowledge sharing' than the term knowledge management. The implementation of knowledge sharing in this school has also not been fully based on real concepts and theories regarding knowledge sharing. Existing knowledge sharing is formed naturally from the creative ideas of the principal and the teachers(Mcdermott \& O'Dell, 2001).

Lack of understanding of knowledge management leads to the lack of achievement of the goals of knowledge management itself (Earl, 2001) (Wiig, 1997). Even though this school has qualified human resources (teachers). A deep understanding of knowledge management is very necessary to increase intellectuals in the school environment (Demarest, 1997) (Quintas, Lefrere, \& Jones, 1997). An audit (assessment) is also needed to measure the effectiveness of the application of knowledge management. Knowledge management is an important part of the learning process of an organization. The knowledge possessed by the organization must be able to provide progress for the organization. For organizations to survive, everyone in the organization must share their knowledge with others. There needs to be good management so that knowledge can be absorbed well in each individual and not just disappear. This requires the support of a good information dissemination infrastructure.

The researchers will explain the school profile along with the achievements in the last few years, as well as the definition, purpose, and implementation of knowledge management. Researchers will also display some improvement in student achievement as a positive impact on the implementation of knowledge management. 


\section{DISCUSSION}

\section{Overview of Muhammadiyah Elementary School of Banguntapan}

This section will discuss some things about Muhammadiyah Elementary School of Banguntapan, the understanding, and purpose of knowledge management, and the implementation of knowledge management implemented in this school. Muhammadiyah Elementary School of Banguntapan was formed to address the influence of globalization and the rapid progress of science and technology which resulted in a shift in the values of life that affect children's development.The vision and mission of this school are to create Muslims who are intelligent, noble, healthy, personable, and responsible for the nation and state. Muhammadiyah Elementary School of Banguntapan graduates are expected to have behavior that is in accordance with Islamic values and norms, independent, responsible, has academic competence for further study, and is able to compete and work together. In implementing the vision and mission, this school provides Islamic knowledge that is balanced in balance with science and technology

This Islamic school has intra-curricular and extra-curricular activities. Intra-curricular activities include general and religious learning activities with remedial programs and enrichment. Some extracurricular activities at this school are Art, English, Art Club, Marching Band, Tapak Suci, Hizbul Wathan, Choir, Futsal, Little Doctor, Wushu, Math Club, Tahfizh (Quran memorization), and Science Club. In addition, the school is also equipped with the Muhammadiyah typical curriculum namely ISMUBA (AlIslam, Arabic, and Muhammadiyah).

The principal of Muhammadiyah Elementary School of Banguntapan explained that learning in this school is student-centered, namely, the pattern of education that emphasizes learning based on 4 pillars of education, namely learning to know, learning to do, learning to be, and learning to live together. He added that the entire learning process is always aimed at developing student's multiple intelligence in joyful learning. In implementing the development of multiple intelligence and joyful learning, teachers in this school carry out various approaches and teaching methodologies. This teaching approach and methodology requires knowledge, skills, training, and the willingness to learn from the teachers. The seriousness, hard work and cohesiveness of all school components especially the teachers produced good results. Figure 1. explain A number of achievements have been achieved by students at Muhammadiyah Elementary School of Banguntapan. 
Figure 1. School achievement

\begin{tabular}{cccc}
\hline Events & Achievements & Level & Year \\
\hline Tapak Suci & $1,2,3$ & Bantul & 2019 \\
Angklung Festival & 1 & Bantul & 2019 \\
Pencak Silat & 1 & Bantul & 2019 \\
Tahfidzul Qur'an & 1 & Bantul & 2019 \\
Qiro'ah & 1 & Bantul & 2019 \\
Football & 2 & All Elementary & 2019 \\
& & Schools in DIY & \\
O2SN & 3 & Bantul & 2019 \\
UASBN & 3 & North Bantul & 2018 \\
\hline
\end{tabular}

Figure 1. shows that in the last two years, the school has been able to obtain a proud achievement. The school won 14 medals in several competitions

\section{Knowledge Management}

The word management comes from Latin, manus, which means hand and agere, which means doing. The words are combined into a manager means to handle. In Arabic, management is defined as idaarah, which comes from the word adaara, which is regulated (Ali Ma'shum, 1997: 384-385). While in the English-Indonesian dictionary by John M. Echols and Hasan Shadily (2006: 359), management comes from to manage which means managing, managing, implementing, managing, and treating. From the word appears management nouns, and managers (people who are in charge of regulating). Finally, management is translated into Indonesian into manajemen or mengatur. The management itself, in the Indonesian Language Dictionary, is interpreted as a process of using resources effectively to achieve goals (Ministry of National Education, 2013: 870).

According to Parker, management is the art of carrying out work through people. In a broad sense, management is planning, organizing, directing, and controlling organizational resources to achieve goals effectively and efficiently (Husaini, 2011: 5). Ramayulis (2008: 362) states that the same meaning as the nature of management is al-tadbir (arrangement). This word is a derivation of the word dabbara (set) which is widely found in the Koran like the word of Allah SWT.:

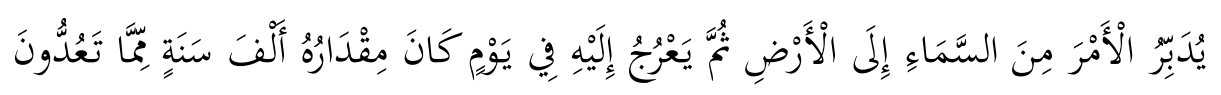

"He arranges all affairs from heaven to earth, then (matters) it raises to Him in one day whose level is a thousand years according to your calculations" (QS. al-Sajdah: 5).

The verse above shows that Allah Almighty is the regulator of nature (Al-Mudabbir / manager). The regularity of the universe is proof of the greatness of God Almighty in managing this nature. However, as a creature created by Allah, humans must manage and manage the earth as well as possible. QS. As-Sajdah paragraph 5 above can be used as a reference and foundation in implementing management. Knowledge or knowledge is the result of a series of processes that process resources into useful information. The data and information shared must be based on the facts, truths, beliefs, judgments, 
experiences, and expertise of the recipient (Whitten, 2004: 23). According to Alter, knowledge is a combination of instincts, ideas, rules, and procedures that lead to actions or decisions. The combination of information, past experience, and expertise will provide valuable knowledge (Agus, 2004: 3).

According to Davenport and Prusak (1998: 84), knowledge is a structured experience, value, contextual information and expert insight that provides a framework for evaluating and combining new experiences and knowledge that produces actions and produces better decisions and produces effective input on dialogue and organizational creativity. Knowledge management can also be interpreted as a discipline that treats intellectual capital as an asset so that it is closely related to the knowledge to be managed. Carl Davidson and Philip Voss (2003) said that knowledge management is the way organizations manage staff, the way people from different places start talking to each other (learning organization) (Carl Davidson, 2003: 32).

\section{Types of Knowledge Management}

a. Tacit Knowledge

Tacit knowledge is the knowledge that is in the mind of each individual according to one's understanding, expertise, and experience. Polanyi in Nonaka (1994: 18) stated that we can know more than we can say. Tacit knowledge is the knowledge that is difficult to formulate and communicate because it is in the minds of each person. Knowledge in someone is like an iceberg. Tacit knowledge can be categorized as personal knowledge. According to Sangkala (2007: 79-80), Tacit knowledge has two dimensions, namely the technical and cognitive dimensions. This technical dimension includes a variety of skills or expertise that are difficult to formalize. This dimension is very subjective, personal, intuitive, and inspirational that emerges from experience. The cognitive dimension consists of beliefs, perceptions, idealism, values, emotions, and mental so that this dimension is not easy to articulate. This dimension also gives an impression or image to someone of reality and future vision to determine the next step of life.

\section{b. Explicit Knowledge}

Explicit knowledge can be expressed in the form of words, can be added up, and can be divided into data, formulas of science, product specifications, manuals, and universal principles. This knowledge is always ready to be formally and systematically transferred to others (Sangkala, 2007: 80). Explicit knowledge is easier to implement because it is obtained from writing, recording, and documented sources so that it can be studied independently. The explicit knowledge in this research is work procedures and technology. Tacit and Explicit knowledge can be converted through four conversion processes, namely: Socialization, Externalization, Combination, and Internalization. Socialization is a sharing process that is created based on interaction and direct experience that causes the transfer of tacit knowledge to another tacit knowledge, e.g. conversation. Externalization is the process of transferring knowledge based on dialogue and reflection that causes articulation of tacit knowledge to be explicit knowledge, e.g. writing 
books, diaries, magazines, journals, etc. The combination is the process of transferring knowledge based on the conversion of explicit knowledge into new explicit knowledge through systemization and the application of explicit knowledge and information. E.g. article summary, book reviewer. Internalization is the process of transferring knowledge based on learning and knowledge acquisition conducted by members of the organization on explicit knowledge that is disseminated throughout the organization through its own experience so that it becomes tacit knowledge for members of the organization. E.g. teacher teaching experience.

\section{The cycle of Knowledge}

A process model of knowledge creation develops on the critical presupposition that personal knowledge is created and enlarged using social interaction between tacit and explicit knowledge. This interaction is called knowledge conversion (Alkhaldi, Olaimat, \& Kohun, 2006).

Figure 2. Model Knowledge Conversion

(SECT Process, Nonaka \& Takeuchi, 1995; Tobing, 2007: 22)

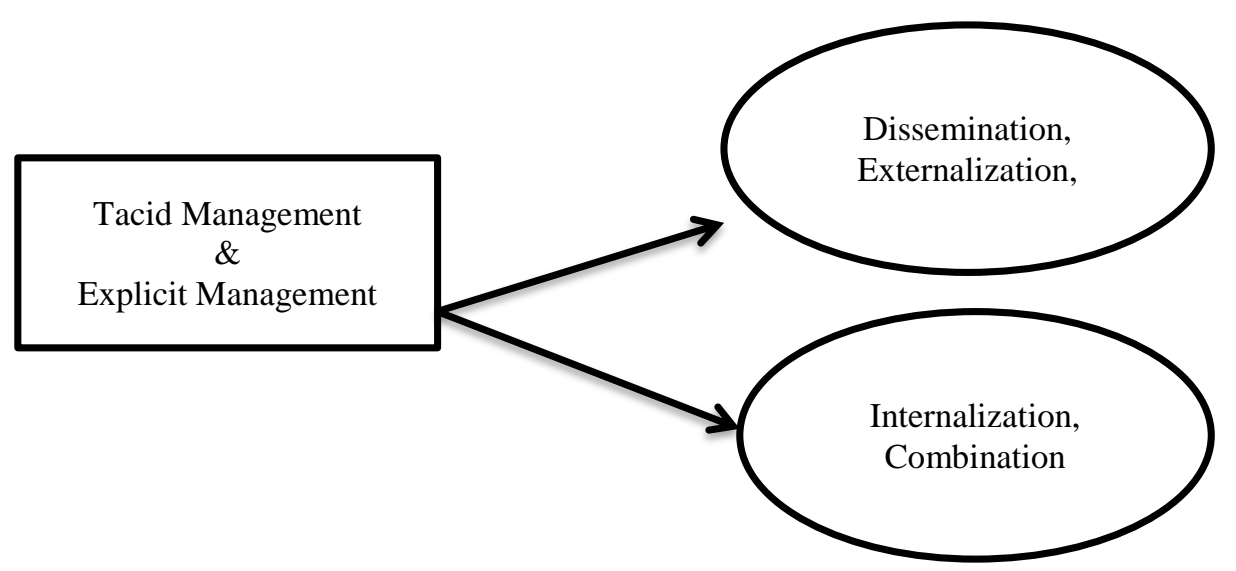

Figure 1. explain, Tacit knowledge based on common sense, and explicit knowledge based on academic accomplishment are both underutilized. Ways knowledge-enabled organizations acquire, measure, teach, share and apply knowledge are discussed and illustrated. Methods to balance the use of tacit and explicit knowledge at work and practice, proven ways to improve the understanding and use of knowledge are presented. Organizations must begin to create worker-centered environments to encourage the open sharing and use of all forms of knowledge (Smith, 2001).

\section{The implementation of Knowledge Management at school}

The implementation of knowledge management in elementary schools is very important because elementary school is one of the basic institutions of knowledge gathering that transfers knowledge to each individual (intangible assets) into organizational assets. Petrides \& Nguyen (2006: 22) say "implementing 
knowledge management strategies and practices requires educational institutions to examine the larger context of information sharing within the organization, specifically how people, processes and technology function within it". Thus, the focus of this research is to find the support of technical policy knowledge management, the process of implementing knowledge management people, the process, the use of technology, and knowledge sharing in higher education knowledge management.

The position and importance of the implementation of knowledge management in higher education institutions in maintaining survival and competitiveness are primarily determined by human capital as an intangible asset inherent in HR. It includes skills and knowledge that not only dwell on the ability to obtain and convert raw materials into products but the ability to work in a global business environment by focusing on the creation and use of intellectual assets. Based on the background of the research above, the title of this research is "Knowledge Management Implementation in Banguntapan Muhammadiyah Primary School.”The application of knowledge management at Muhammadiyah Elementary School of Banguntapan was able to improve the quality and quantity of achievements. One indicator of the successful implementation of knowledge management is the increase in academic and non-academic achievements by students.

a) Identification

The school completely identified its Knowledge Management. This can be interpreted that the school has made a thorough identification of the assets it has. This identification will indicate which fields must be managed.

b) Acquisition

The school identified external conditions or circumstances that are useful in developing School Knowledge capabilities. These steps are also called market analysis, namely creative use of opportunities and knowing the level of competition. In other words, the school mapped the potential of students, mapping talents and interests in compiling extracurricular activities needed by students.

c) Development

Build and manage internal and external knowledge by solving problems/providing solutions to problems faced by students, creating products from students' work, skills, and implementing efficient processes.

d) Sharing

Knowledge management is carried out effectively and evenly within an organization or company. Knowledge management can be in the form of utilization, access to use, and delivery/transfer to advance organizations and companies. Some of the applications of knowledge sharing in Muhammadiyah Elementary School of Banguntapan are Daily sharing. This activity is carried out every day before the learning process during the morning briefing. This is done together in the teacher's room. This activity 
takes around 15 minutes. Weekly sharing. Generally this is done once a week by each parallel class. This school has 4 parallel classes in each grade. The teachers will discuss learning activities and problems that have existed for the past 1 week. All parallel class teachers are present and contribute to providing solutions to problems by sharing creative ideas and experiences.

e) Literacy

This stage was carried out to improve the quality of teaching staff by increasing reading and writing interest. At Muhammadiyah Elementary School of Banguntapan, this literacy program inspires teachers to review books every month where the results of the review are then submitted to the principal and delivered to other teachers in sharing. The results of the review are usually related to learning methods and media that can improve the quality of effective learning.

f) Retention

Schools or companies ensure that existing knowledge is not lost and stay in the company and uses it to improve processes and performance aimed at achieving certain targets. This can be in the form of innovations that are in accordance with the needs of the public (guardians of students and the community).

g) Training, Workshop, and Seminar

One characteristic of favorite schools is the ability to adapt to the development of the world of education. A favorite school is a school with high dynamics. Usually schools like this hold training, workshops, or seminars on a regular basis. Muhammadiyah Elementary School of Banguntapan also did the same thing. The budget allocated for this activity is quite large because these activities are considered as assets that will improve the quality of schools. There are two types of training conducted at this school: 1) Internal school training. Schools bring trainers to train some or all of the teachers. This activity is carried out routinely once a month with varied materials and adapted to school needs, 2) School External Training. The principal sends one or more teachers to attend training outside of school. The school will send different teachers for each event and the selected teacher is adjusted to the capacity and needs of the school. After the training, the teacher is obliged to submit a photocopy of the training documents he follows. The teacher is expected to be able to apply the knowledge gained. On certain occasions, he will be asked to share the knowledge he gets with other teachers.

h) Dissemination

This process is carried out after the teacher has completed certain education training. This dissemination process is carried out with special time allocation with other teachers. This process allows the exchange of information obtained by teachers from the training they have participated in before. This program is usually incidental.

i) Lesson Plan Consultation

Lesson plan means a teaching plan. Each teacher is required to make a lesson plan before teaching in class. This includes opening, teaching methods \& strategies, teaching-learning style approaches, the 
achievement of learning indicators, classroom mastery, time management, and evaluation. All of that must be appropriately planned and then consulted with the principal or vice-principal. The consultation allows the sharing of knowledge. Such consultations may result in revisions and corrections to both the teacher and the lesson plan consultant. Both the teacher and the consultant will get a variety of important information that can improve the quality of lesson plans at the school.

j) Article, Clipping, and Educational Journals

Another way to keep up with developments in the field of education is to keep abreast of educational information and news through the media. Exciting and important educational news is cut and photocopied. The librarian will use the original cut as clipping, and the copy as part of the wall magazine. Clipping is made according to a specific theme and archived according to the time. Schools should subscribe to various print media such as newspapers and related-to-education-magazines. It aims to ensure that all components of the school, both teachers, employees, and students, can keep up with news and information.

\section{k) Mailing List}

Media sharing which is also proven reliable is a mailing list. Today almost everyone has e-mail. The main advantage of this media is its ability to capture communities and share information within a group. This media is also able to disseminate information widely and quickly. There are 3 forms of mailing lists related to education; 1) Teacher's mailing list that functions for various information, 2) Mailing list for parents of students, and 3) Mailing list for the public. Teacher-specific mailing lists are used to share information, knowledge, experience, new information, or problems that exist within the school. Parent mailing lists are used to convey ideas, criticisms, and questions about school. The parents will also get a variety of important information from this mailing list. Public mailing lists are used to build school relations and media promotions. It also becomes a means of communication with other schools or communities outside of school.

1) Favorite school community

To obtain the greatest benefit of knowledge management, the institution should also actively identify and acquire quality knowledge in the external environment of the organization. It is interesting that the current "favorite" paradigm shows the ability and desire of a school to improve the quality of the school through collaboration with other schools. 


\section{CONCLUSION}

Superior and quality human resources are important factors for good companies engaged in services and non-services, including educational institutions such as schools. At present, where competition between school institutions is increasingly high, people realize that knowledge is an important factor in creating superiority. The Muhammadiyah Elementary School of Banguntapan has the potential to continue to grow. This school has outstanding quality teachers. However, this has not yet been balanced with the management of knowledge to increase the human intellectual resources of the institution. If knowledge management is implemented optimally, researchers are confident and believe that the school is able to improve its quality. The researcher hopes that Muhammadiyah Elementary School of Banguntapan is able to realize the potential of the school it has and wants to apply knowledge management. Good management of knowledge will improve the quality of all elements of education in this school.

\section{REFERENCES}

Agus Mulyanto, (2009). Sistem informasi: Konsep dan Aplikasi, Yogyakarta: Pustaka Pelajar,

Alkhaldi, F. M., Olaimat, M., \& Kohun, F. (2006). Knowledge Conversion and Transfer: A Mathematical Interpretation. Interdisciplinary Journal of Information, Knowledge \& Management, 1 .

Ali Ma'shum \& Zainal Abidin Munawwir, (1997). Kamus Al-Munawwir, Surabaya: Pustaka Progresif, Carl Davidson \& Philip Voss, (2003). Knowledge Management: An Introduction to Creating Competitive Advantage from Intellectual Capital, New Delhi: Vision Books,

Davenport T.H \& Prusank L., (1998). Working Knowledge: How Organizations Manage What They Know. Cambridge: Harvard Business School Press MA,

Departemen Pendidikan Nasional, (2013). Kamus Besar Bahasa Indonesia Pusat Bahasa, Jakarta: Gramedia Pustaka Utama.

Demarest, M. (1997). Understanding knowledge management. Long Range Planning. https://doi.org/10.1016/s0024-6301(97)90250-8

Earl, M. (2001). Knowledge management strategies: Toward a taxonomy. Journal of Management Information Systems. https://doi.org/10.1080/07421222.2001.11045670

Husaini Usman, (2011). Manajemen: Teori, Praktik dan Riset Pendidikan, Jakarta: Bumi Aksara.

John M. Echols \& Hasan Shadily, (2006). Kamus Inggris Indonesia, Jakarta: Gramedia Pustaka Utama.

Manuj, I., \& Mentzer, J. T. (2008). Global supply chain risk management strategies. International Journal of Physical Distribution and Logistics Management. https://doi.org/10.1108/09600030810866986

Mavodza, J., \& Ngulube, P. (2012). Knowledge management practices at an institution of higher learning. SA Journal of Information Management. https://doi.org/10.4102/sajim.v14i1.496

Mcdermott, R., \& O'Dell, C. (2001). Overcoming cultural barriers to sharing knowledge. Journal of Knowledge Management. https://doi.org/10.1108/13673270110384428

Nuryana, Z. (2017). Knowledge Management sebagai Upaya Pengembangan Learning Organization di Lembaga Pendidikan Islam. LITERASI Jurnal Pendidikan, Volume VII, 12-20. https://doi.org/http://dx.doi.org/10.21927/literasi.2017.8(1).11-19

Nonaka I., A Dynamic Theory of Organizational Knowledge Creation. Organization Science, Volume 5, Number 1. Retrieved from http:/www.jstor.org/stable/2635068.

Paul Tobing, (2007). Knowledge Management: Konsep, Arsitektur dan Implementasi, Jakarta: Grha Ilmu. 
Petrides L.A. \& Nguyen L., (2006). Knowledge Management Trends: Challenges and Opportunities for Educational Institutions, United States America: Information Science Publishing.

Ramayulis, (2008). Ilmu Pendidikan Islam, Jakarta: Kalam Mulia.

Quintas, P., Lefrere, P., \& Jones, G. (1997). Knowledge management: A strategic agenda. Long Range Planning. https://doi.org/10.1016/s0024-6301(97)90252-1

Salame, I. I., \& Nazir, S. (2019). The Impact of Supplemental Instruction on the Performance and Attitudes of General Chemistry Students. International Journal of Chemistry Education Research, 3(2), 53-59. https://doi.org/10.20885/ijcer.vol3.iss2.art1

Sangkala, (2007). Knowledge Mangement, Jakarta: Rajawali Press.

Smith, E. A. (2001). The role of tacit and explicit knowledge in the workplace. Journal of Knowledge Management, 5(4), 311-321. https://doi.org/10.1108/13673270110411733

Whiten L. Jeffry, (2005). Metoda Desain dan Analisis Sistem Edisi 6, Yogyakarta: Andi \& McGraw-Hill. Wiig, K. M. (1997). Knowledge Management: An Introduction and Perspective. Journal of Knowledge Management. https://doi.org/10.1108/13673279710800682 